\title{
Organic Farm, Organic Food Steps Towards a Sustainable Agriculture (with Hungarian and Slovenian Examples)
}

\author{
An Introduction to the Thematic Block
}

\begin{abstract}
Anikó Báti
Senior research fellow, Hungarian Academy of Sciences, Research Centre for the Humanities, Institute of Ethnology
\end{abstract}

At the beginning of the $21^{\text {st }}$ century, ethnographic food culture research looks at foodways not as a comparison of the individual social strata or village-town relations, but focuses rather on consumption habits. Among the consumption groups, clearly distinguishable are those that oppose globalization, trends in the food industry and food trade, and the oversupply of supermarkets. If and when these groups seeking a health-conscious diet have the option, they try to put on their tables fresh, locally-produced products from controlled, certified farms or home-made produce and food. In consumer decisions, therefore, the origin of food, a personal, trust-based producer-customer relationship, and chemical-free, environmentally friendly production play an increasingly important role. In this issue of Acta Ethnographica Hungarica, we can see the functioning of this value system in everyday practice through a collection of case studies, examples of Hungarian and Slovene settlements or small communities within them. The topicality of the issue is evidenced by the fact that it was also the theme of the 2016 conference Place of Food Production: Origin, Identity, Imagination, organized in Germany by the largest international organization in food culture research, the SIEF International Ethnological Food Research Group. The presentations demonstrated how the global food supply affects local production and consumption, enhancing the importance of identity-forming locality, and how the specific characteristics of traditional food production oriented towards the market and tourism may be preserved. The economic and social history of this process, which can nowadays be documented with the tools of ethnographic food culture research, goes back in Hungary, for example, to the middle of the $20^{\text {th }}$ century.

The large-scale reorganization of agriculture, during which the individual estates were abolished in the 1960s, has basically transformed the production framework in Hungary. Many abandoned agriculture at that time, changed their way of life, started working in cities, industries, in the service sector. In the villages, only the backyard garden endured as individual property. The purpose of small-scale agricultural production was partly to gain income, or to supplement income and to expand the unequal commercial supply. The earlier frameworks of household organization were transformed, and the pursuit of partial self-sufficiency in food production slowed down. 
In parallel with women entering the workplace, they increasingly relied on in-store food supplies, not only in cities but also in villages.

After 1990, following the regime change, another major restructuring of ownership took place in agriculture in line with the market economy framework. Land became a real private property once again. Agricultural cooperatives were abolished and many lost their jobs. Due to the structural transformation of agriculture, production declined sharply by $50 \%$ in the 1990 s in Hungary. However, very few returned to the former form of agriculture as independent farmers. The knowledge required for independent farming has been either lost or has become outdated in recent decades. After 1990, many family farms were unable to rebuild because they did not have the necessary capital. Only a narrow stratum of small-scale farmers emerged, but their survival is still fairly uncertain today. Their numbers have declined steadily in recent years. ${ }^{1}$

One of the long-term viable solutions to the quandary of Hungarian agriculture which started in the 1980s and intensified with the political regime change in 1989 may be a shift towards sustainable farming (KAJNER et al. 2013). Sustainable agriculture is the reproduction of resources, which has a positive impact on the natural environment, assists in the survival of rural communities in multiple ways, and improves the quality of life through food production. Ethnographer Anikó Báti's study, From Hernádszentandrás to BioSzentandrás. An Example of a Sustainable Bio-farm in Hungary, presents an organic farm in a disadvantaged village in Hungary ${ }^{2}$ as a sustainable agricultural initiative. (In colloquial Hungarian, as a prefix in complex words, bio $^{3}$ and eco are used as equivalents of the English word 'organic' in the names of farming methods and products, but clarification of the terminology would go beyond the thematic framework of this journal, so we will not discuss it here.) One of the peculiarities of the small-scale

\footnotetext{
${ }^{1}$ Between 2000 and 2013, the number of individual farmers in Hungary declined from 900,000 to 500,000 . Most of them produce only for their own consumption, only approx. one third sells their products on the market. MaGYAR MezőGAZDASÁG 2016. [Hungarian Agriculture 2016] https://www. ksh.hu/docs/hun/agrar/agrarium2016/agrarium_2016_04be.pdf (accessed December 10, 2017).

${ }^{2}$ In today's Hungarian agriculture, chemical-free, environmentally conscious farms are present in a much smaller proportion. Much of their products are shipped abroad in the absence of a domestic solvent market. (See also: MagYar MezöGazdasáG 2016. [Hungarian Agriculture 2016] https:// www.ksh.hu/docs/hun/agrar/agrarium2016/agrarium_2016_04be.pdf, accessed December 10, 2017). This trend is a serious obstacle, for example, in the reform efforts of school cafeterias. In the survey providing an international overview (WILLER - LERNOUD 2016), the figures for Hungarian organic farming for 2014 (the main crops grown organically are cereals, plants harvested green and oilseeds) are as follows: organic agricultural land: 124,841 hectares organic share of the total farmland: $2.7 \%$ organic producers 1,672 person organic vegetable land: 1,854 hectares organic share of the total vegetable land: $4.2 \%$

${ }^{3}$ Organic farming in Hungary first gained ground in the 1980s. In 1983, the first non-governmental organization, Biokultúra Klub [Bioculture Club] was founded, followed in 1987 by Biokultúra Egyesület [Bioculture Association], which was succeeded in 2005 by Biokultúra Szövetség [Bioculture Alliance]. They focus on environmentally conscious approaches and healthy lifestyles, the propagation of organic farming, and the promotion of eco-product consumption. They organize fairs, events, and informational lectures, prepare publications, and operate a web site. BIOKULTúRA 2017 http://www.biokultura.org/hu/ (accessed December 10, 2017).
} 
agricultural enterprise under examination is that the local government is the entrepreneur who has established the vegetable and fruit garden and the processing plant by relying on local resources and by means of grant moneys. The study reveals that sustainability not only affects agriculture but also includes improving the living conditions and the social situation of the settlement, as well as the rational use of resources. An important condition of success, however, is the broad acceptance of basic principles such as conscious consumer habits, the adaptation of the structure of production to local conditions, and a background of long-term economic policy and necessary financial resources. The fieldwork-based study presents the process of the organic farm's development and market-based sustainability, and the role of the garden in the life of the community.

In the decades following World War II, the earlier practice still continued in Hungary, albeit in a decreasing degree, but due to unsteady food supplies, both rural and urban households sought to supplement their food reserves with their own vegetables and fruits. The cultivation of small gardens was a popular recreational activity for many people. After the political regime change, and with the establishment of supermarket networks, everyone had access, regardless of the season, to not only domestic but also foreign agricultural products. Thus, more and more people gave up cultivating privately owned or rented gardens. By contrast, as a quasi-protest against the habits of consumer society, in Budapest, for example, community gardens in urban spaces have been continuously established since 2012, ${ }^{4}$ within the framework of urban agriculture. In 2017, there were approx. 60-70 such gardens in operation nationally. ${ }^{5}$ In these communal gardens, the goal is not only environmentally-conscious, chemical-free gardening and fruit and vegetable production for one's own consumption, but also community life (GYöRGY 2014) and the transfer of basic horticultural knowledge. Ethnography Ph.D. candidate Gergö Hajba's study based on participant observation, Aspects to the Understanding of the Social Dynamics of Organic Food through the Example of a Community Garden in Budapest, presents the operation of a metropolitan community garden in the VIII. district. A community garden was established five years ago on an empty private lot between two buildings as a neighborhood initiative. The main research question was: how do the gardeners express what they know about organic foods, and how do they integrate it all into their foodways in the urban space? (In fact, general knowledge of organic foods is still very limited and incomplete in Hungary, and scientific data about this is even more sparse.) The study highlights self-production as the main value indicated by the informants, even though they receive criticism from outside the community regarding urban pollution and other challenges. Although the circumstances are very different, one of the key elements of the community's operation, the preservation and transfer of knowledge related to agricultural work, is of the same importance as in the rural example presented in the study by Anikó Báti.

\footnotetext{
${ }^{4}$ The first community garden opened in 2012 with 26 beds of approximately $5 \mathrm{~m}^{2}$. The initiator, the launcher of the entire movement, Gábor Rostás, was president of the Municipal Gardens Association. See also: VÁrosi KERTEK 2017 [Urban Gardens 2017] http://www.varosikertek.hu/ot-eves-az-elsokis-pesti-kert/ (accessed December 10, 2017).

${ }^{5}$ There is no exact figure on the number of community gardens in 2017 , this is just an estimate. See also: VÁROSI KERTEK 2017 [Urban Gardens 2017] http://www.varosikertek.hu/ot-eves-az-elso-kispesti-kert/ (accessed December 10, 2017).
} 
Eco-villages have been created as an attempted solution to the ecological crisis induced by consumer society, where the goal is not only a sustainable and eco-friendly farming but also community building, the preservation of traditional knowledge, and the transfer of collected personal experiences and information. It is in this respect that Judit Farkas's study, 'There are no recipes'. An Anthropological Assessment of Nutrition in Hungarian Eco-villages, is related to the previous writings. As a cultural anthropologist, Judit Farkas has been studying the topic in Hungary for 10 years, focusing mainly on social phenomena and food culture. In her current article, she documents the eating habits of a small community of newcomers - partly agricultural scientists, botanists, horticultural educators - within a Hungarian village. We get an insight into the details of the attempts at self-sufficiency that include cultivated and wild plants - and the possible interpretations of these - based on the author's participant observation fieldwork.

Up until the first half of the $20^{\text {th }}$ century, foraged wild plants and fungi were regularly present in traditional foodways during various seasons of the year, regardless of the social layer, although in varying quantities. Béla Gunda's work (GuNDA 2011) summarized the ethnographic findings of collecting and using wild plants. In the peasant household, they were not only consumed as food, fed to animals as feed, but also used as a medicine or as storage equipment, and they were also used as a magical tool for spells. Due to intensive cultivation and weed control, however, the natural collection points have disappeared, and horticulture and the commercial supply of foodstuffs caused the place and role of wild plants in the Hungarian kitchen and medicine to have diminished since the second half of the $20^{\text {th }}$ century. Biologist Andrea Dénes gives a detailed overview of the foraged species that are commercially available in the markets of a city in Southern Hungary with favorable environmental conditions in her study, Wild Plants for Sale in the Markets of Pécs Then and Now (Baranya, Hungary). Starting from a current-day example and also surveying the Hungarian ethnographic literature on the topic, she shows how the supply of wild plants has changed. These products are merely delicacies today, their role in diet minimal. They are nonetheless a good indicator of the exciting (from the perspective of research) extremes that manifest in consumer habits and current trends in commercial supply. For example, a previously forgotten spice has become so popular today that its natural habitats need to be safeguarded from excessive, less environmentally conscious foraging.

During the mapping of the living cultural heritage of Slovenia, the Institute of Slovenian Ethnology of the Research Center of the Slovene Academy of Sciences and Arts paid special attention to food culture in 2009-2011. Cooking and eating habits and associated customs can carry a wide range of knowledge both at the family level and at the widest community level, as a kaleidoscopic impression of ethnic, local and regional traditions. Maja Godina Golija's study, The Growing Importance of Local Pumpkin Seed Oil Production in Slovenia, shows through the example of pumpkin seed oil, which was not so prestigious in the Slovenian kitchen 200 years ago, how today's consumption patterns have changed as a result of influences of health-conscious diet trends, ${ }^{6}$ as well as tourism. Pumpkin seed oil has now become an important expression of local identity in the northeastern part of Slovenia. The product is also protected

\footnotetext{
${ }^{6}$ On the topic, see, for example: TöRőCsIK 2011.
} 
within the European Union with a Protected Designation of Origin trademark. The darkcolored, locally grown oil, which has a unique flavor and is beneficial to health, had previously only appeared on the tables of the lower social strata. In the Mediterranean cuisine, it was used as a dressing for salads and vegetable dishes, similarly to olive oil - just a cheaper version of it. Nowadays, however, pumpkin seed oil is also conceived of in and outside the region as a local specialty, an ethnic marker in food culture, such as among the Slovenes living in the Porabje [Vendvidék] region of Hungary. Today it is used not only in salads but also in cooking, and it has even made its way into confectionery and chocolate as a flavoring. The author describes the past and present of the production of pumpkin seed oil, highlighting the changes that have been induced by changes in consumption patterns, mainly as part of today's taste change and healthy diet. It also points out that although the Hungarian-Slovenian political border virtually divides the region under examination, it does not constitute a cultural border. Through fieldwork in Slovenia and Hungary, the identity-shaping importance of food emerged. The study fits in with the line of research which, during the aforementioned conference organized by the SIEF International Food Research Group (in which the author serves as vice president), presented at an international level a number of similar examples of these processes, in which each food or its way of production is given a prominent role in the formulation of self-identity, and around which festive occasions and festivals are also organized.

Many of the elements of traditional peasant farming knowledge accumulated over the centuries, previously considered to be outdated, still live on in the reform attempts of agricultural production seeking adequate responses to environmental challenges since the end of the $20^{\text {th }}$ century. In many cases, communities need to be re-educated about this from the outside. The peasant roots of farming called organic today are in most cases not openly discussed, visible only through the eyes of ethnographers, as reflected in the above-mentioned studies. For this reason, documenting and interpreting recent phenomena is an important task of ethnographic research.

\section{REFERENCES CITED}

\section{BIOKULTÚRA}

2017 http://www.biokultura.org/hu/ (accessed December 10, 2017).

CZELLERNÉ DarócZi, Éva

2014 Segédanyag városi kertészkedéshez: Közösségi kertek bio módra. [Auxiliary Materials for Urban Gardening: Community Gardens in Bio Style.] (Compiled by: Gerencsér, Margit) Budapest: Magyar Biokultúra Szövetség. www.kornyezettudatoselet.hu/varosi_kerteszkedes_biomodra.pdf (accessed December 10, 2017)

Gunda Béla

2011 A vadnövények gyüjtögetése. [Foraging for Wild Plants.] In PALÁDI-Kovács Attila (ed) Magyar Néprajz II. Gazdálkodás. 11-40. Budapest: Akadémiai Kiadó. 
GYöRGY, Bálint

2014 Közösségi kertek: Kisközösségek a fenntarthatóbb városi életért. [Community Gardens: Small Communities for a More Sustainable Urban Life] ELTE Társadalomtudományi Kar. Thesis. Manuscript. http://www.varosikertek.hu/wpcontent/uploads/2014/06/Közösségi-kertek.pdf (accessed December 10, 2017).

KAJNER, Péter - LÁNYI, András - TAKÁCs Sánta András (eds)

2013 Afenntarthatóságfelévalóátmenetjó példái Magyarországon. [GoodExamples of Transition to Sustainability in Hungary]. Budapest: MIS-ÖKO Kft. http:// humanokologia.tatk.elte.hu/wp-content/uploads/a_fenntarthatosag_fele.pdf (accessed September 20, 2016)

MAGYAR MEZŐGAZDASÁG

2016 [Hungarian Agriculture 2016] https://www.ksh.hu/docs/hun/agrar/ agrarium2016/agrarium_2016_04be.pdf (accessed December 10, 2017).

TöRÖCsIK, Mária

2011 Food trendek és vásárlói csoportok. [Food Trends and Customer Groups] http://www.trendinspiracio.hu/letoltesek/dokumentumok/food_trendek.pdf (accessed July 18, 2013).

VÁROSI KERTEK

2017 [Urban Gardens] http://www.varosikertek.hu/ot-eves-az-elso-kis-pesti-kert/ (accessed December 10, 2017).

WiLLER, Helga - LeRnoud, Julia (eds)

2016 The World of Organic Agriculture. Statistics and emerging trends. Frick Bonn: 2016. Research Institute of Organic Agriculture (FiBL) and IFOAMOrganics International. The book is available at http://www.organic-world.net/ yearbook/yearbook-2016/pdf.html (accessed December 10, 2017). 
Báti, Anikó, Ph.D., is a senior research fellow at the Institute of Ethnology, Research Centre for the Humanities, Hungarian Academy of Sciences. She graduated with an M.A. in Historical Studies and an M.A. in Folkloristics and European Ethnology from the József Attila University of Szeged in 1997. She received her Ph.D. in Ethnography and Cultural Anthropology from the European Ethnology Doctoral School of Eötvös Loránd University, Budapest in 2005. Since 2009 she has been employed at the Institute of Ethnology, Research Centre for the Humanities, Hungarian Academy of Sciences.

Her research topic is changes in contemporary food culture. She conducts fieldwork in the $20^{\text {th }}$ district of Budapest and the northern parts of Hungary, and studies school canteens, festive and everyday food and eating habits, cultural background, and lifestyles. She has written two monographs and several scientific articles and papers, especially on food culture. She is editor-in-chief of Életmód és Tradíció [Life Style and Tradition], a book series of the Institute of Ethnology, and she edited numerous ethnographic books. Since 2013 she has been editor of Ethnography, a journal of the Hungarian Ethnographical Society. She was the Secretary of the Material Culture Section of the Hungarian Ethnographical Society (2009-2015), and since 2015 she has been the Secretary of the Hungarian Ethnographical Society. She is a member of the SIEF International Ethnological Food Research Group, and has regularly participated in its conferences since 2012. 
